\title{
EFFECT OF CINNAMOMUM ZEYLANICUM BLUME ESSENTIAL OIL ON THE GROWTH AND MORPHOGENESIS OF SOME POTENTIALLY PATHOGENIC ASPERGILLUS SPECIES
}

\author{
Egberto Santos Carmo ${ }^{1}$; Edeltrudes de Oliveira Lima²; Evandro Leite de Souza ${ }^{3 *}$; Frederico Barbosa de Sousa ${ }^{4}$
}

${ }^{1}$ Laboratório de Tecnologia Farmacêutica, Universidade Federal da Paraíba, João Pessoa, PB, Brasil; ${ }^{2}$ Laboratório de Micologia, Departamento de Ciências Farmacêuticas, Centro de Ciências da Saúde, Universidade Federal da Federal da Paraíba, João

Pessoa, PB, Brasil; ${ }^{3}$ Laboratório de Microbiologia de Alimentos, Departamento de Nutrição, Centro de Ciências da Saúde, Universidade Federal da Paraíba, João Pessoa, PB, Brasil; ${ }^{4}$ Laboratório de Microscopia e Imagem Biológica, Centro de Ciências da Saúde, Universidade Federal da Federal da Paraíba, João Pessoa, PB, Brasil

Submitted: July 05, 2007; Returned to authors for corrections: November 26, 2007; Approved: January 20, 2008.

\begin{abstract}
Cinnamomum zeylanicum Blume is known for a wide range of medicinal properties. This study aimed to assess the interference of $C$. zeylanicum essential oil on the growth and morphogenesis of some potentially pathogenic Aspergillus species. The essential oil presented strong antifungal effect causing the growth inhibition of the assayed strains and development of large growth inhibition zones. $\mathrm{MIC}_{50}$ and $\mathrm{MIC}_{90}$ values were 40 and $80 \mu \mathrm{L} / \mathrm{mL}$, respectively. 80,40 and $20 \mu \mathrm{L} / \mathrm{mL}$ of the oil strongly inhibited the radial mycelial growth of A. niger, A. flavus and A. fumigatus along 14 days. 80 and $40 \mu \mathrm{L} / \mathrm{mL}$ of the oil caused a $100 \%$ inhibition of the fungal spore germination. Main morphological changes observed under light microscopy provided by the essential oil in the fungal strains were decreased conidiation, leakage of cytoplasm, loss of pigmentation and disrupted cell structure indicating fungal wall degeneration. It is concluded that $C$. zeylanicum essential oil could be known as potential antifungal compound, particularly, to protect against the growth of Aspergillus species.
\end{abstract}

Key words: Aspergillus, Cinnamomum zeylanicum Blume, essential oil, antifungal activity.

\section{INTRODUCTION}

Aspergilli are ubiquitous fungi found in air, soil, plants and decayed organic materials. Human contamination by Aspergillus has been related to the inhalation of conidia, colonization of wounds and/or penetration in human tissues through surgical interventions $(13,30)$. Aspergillosis is an opportunistic infection which can attack the lungs, ears, eyes, digestive system, kidneys and brain $(12,19)$.

Aspergillosis generally rises as a respiratory disease characterized for the presence of granulomatous lesions in lungs or bronchi, followed by dissemination to other organs throughout the bloodstream $(3,14)$. Cutaneous aspergillosis, aspergillar otomycosis, aspergillar onychomycosis, invasive lung aspergillosis, aspergillar sinusitis, immunoallergic aspergillosis, aspergilloma and mycotoxicosis are some clinical forms of aspergillosis $(19,30)$.

The growth of Aspergilli in foodstuffs is toxicologically significant since some species are known to produce mycotoxins. Aflatoxins- $\mathrm{B}_{1}, \mathrm{~B}_{2}, \mathrm{G}_{1}$ and $\mathrm{G}_{2}$ (produced by A. flavus and A. parasiticus), aspergillic acid (produced by A. flavus), hydroxyaspergillic acid (produced by A. flavus), ochratoxins (produced by A. ochraceus), oxalic acid (produced by A. flavus and A. glaucus), terreic acid (produced by $A$. terreus) are some mycotoxins produced by Aspergillus species $(6,37)$. The consumption of mouldy products can cause human or animal mycotoxicoses, and more importantly some mycotoxins are potent carcinogens $(23,26)$.

Resistance of Aspergilli to some clinically used antifungals brings a worrying clinical prognostic in people attacked by

*Corresponding Author. Mailing address: Laboratório de Microbiologia de Alimentos, Departamento de Nutrição, Centro de Ciências da Saúde, Universidade Federal da Paraíba, João Pessoa, Paraíba, Brasil. E-mail: evandroleitesouza@ccs.ufpb.br 
aspergillosis $(11,14)$. For over fifty years antibiotics have been applied for treating or inhibiting infections. The wide use and sometimes misuse of chemo-antimicrobials in both human and animal medicine has been responsible for the selection of resistant strains $(17,21)$.

Regarding the increasing clinical importance given to fungi causing infections and the development of drug resistance many scientific studies focusing the antifungal properties of plant products have been carried out $(4,41)$. Antifungal effect of medicinal plants and derivatives has been scientifically proven in assays with essential oils, extracts and isolated phytochemicals $(20,26,42)$. Essential oils as antimicrobial agents present two main characters: their natural origin generally means more safety to people and environment; and they can be considered at low risk for development of microbial resistance since they are mixtures of compounds which may present different mechanisms of antimicrobial activity $(15,29)$.

Cinnamomum zeylanicum Blume, Lauraceae, has many biological properties as analgesic, antiseptic, antispasmodic, aphrodisiac, astringent, carminative, haemostatic, insecticidal and parasiticide. Barks from branches, without the epidermis and subereous layer, is marketed as the commercial cinnamon which has long use in perfumery, culinary and native medicine fields $(2,20)$. Previous research has revealed interesting antimicrobial effect in $C$. zeylanicum essential oil $(10,27,28)$. Camphene, linalool, $\alpha$-phelendrene, $\alpha$-terpinene, limonene, $\beta$ cymene, $\alpha$-cariophyllene, cinnamaldheyde and eugenol are some of the compounds found in C. zeylanicum essential oil $(24,44)$.

The present study aimed to evaluate the effect of $C$. zeylanicum Blume essential oil on the growth and morphogenesis of some Aspergillus species known as potential etiological agent of fungal infections.

\section{MATERIALAND METHODS}

\section{Essential oil}

C. zeylanicum Blume essential oil was supplied by Ferquima Ind. Com. Ltda. (Vargem Grande Paulista, São Paulo, Brazil) and its quality parameters (appearance, color, purity, odor, density $20^{\circ} \mathrm{C}$, refraction index $-20^{\circ} \mathrm{C}$ ) were described in an accompanying technical report. The essential oil was assayed at concentrations ranging from 320 to $5 \mu \mathrm{L} / \mathrm{mL}$ and the solutions were prepared according to Souza et al. (42).

\section{Fungal strains}

Aspergillus fumigatus (ATCC-16913 and ATCC-40640), A. niger (P-03 and LM-257), A. flavus (ATCC-16013 and LM-247), A. parasiticus (ATCC-15517 and NRRL-2999), A. terreus (UP03 and ATCC-7860) and A. ochraceus (ATCC-7860 and LM06) strains were used as test microorganisms. These strains were obtained from the Microorganisms Collection, Laboratory of Clinical Mycology, Department of Pharmaceutical Sciences,
Health Sciences Center, Federal University of Paraíba, Brazil. Stock cultures were maintained on Sabouraud agar (SA) slants and stored in a refrigerator $\left(7^{\circ} \mathrm{C}, \pm 1^{\circ} \mathrm{C}\right)$.

\section{Minimum Inhibitory Concentration - MIC}

The MIC of the essential oil was determined by a qualitative method using the solid medium diffusion procedure (22). For this, $1 \mathrm{~mL}$ of the fungal homogenous suspension (approximately $10^{6}$ spores $/ \mathrm{mL}$ ) prepared according to Rana et al. (32) was uniformly spread on sterile SA Petri dishes. After inoculum absorption by SA, wells were made using sterile glass stems (diameter $6 \mathrm{~mm}$ ) which were filled with $50 \mu \mathrm{L}$ of the essential oil solution. The incubation period was $7-10$ days at $25-28^{\circ} \mathrm{C}$. At the end of the incubation period, the MIC was the lowest essential oil concentration showing growth inhibition zones with diameter equal to or greater than $10 \mathrm{~mm}(41,42)$.

Amphotericin B $(100 \mu \mathrm{g} / \mathrm{mL})$ and ketoconazole $(50 \mu \mathrm{g} / \mathrm{mL})$ were used as control using the solid medium diffusion procedure using filter paper discs (Cecon, diameter $6 \mathrm{~mm}$ ) (7). The control of viability of the assayed fungal strains was carried out by observing their capability of growing on SA without adding the essential oil or standard antifungals.

\section{Mycelial growth inhibition}

Inhibition of the fungal mycelial growth was determined using the poisoned substrate technique by the daily measure of the radial mycelial growth on SA added of 80,40 and $20 \mu \mathrm{L} /$ $\mathrm{mL}$ of the essential oil $(1,15)$. For this, a $2 \mathrm{~mm}$ plug taken from a 10-days-old fungal colony cultivated on SA slants was placed on the center of the sterile SA Petri dishes containing the essential oil and incubated at $25-28^{\circ} \mathrm{C}$. At different time intervals $(1,2,4,6,9$ and 14 days) of incubation, the radial mycelial growth was measured $(\mathrm{mm})$ using calipers. The control was the observation of the radial mycelial growth on SA added of ketoconazole $(50 \mu \mathrm{g} / \mathrm{mL})$ and without adding the essential oil.

\section{Spore germination assay}

An aliquot of $0.2 \mathrm{~mL}$ of each concentration of the essential oil $(80,40$ and $20 \mu \mathrm{L} / \mathrm{mL})$ was mixed with $0.2 \mathrm{~mL}$ of the fungal spore suspension (approximately $10^{6} \mathrm{spores} / \mathrm{mL}$ ). The mixture was placed on separated glass slides which were incubated in a moisture chamber at $25-28^{\circ} \mathrm{C}$ for 24 hours. At the end of the incubation period, each slide was fixed with lacto-phenol-cotton blue stain and observed under the microscope for spore germination. Control without essential oil was tested in the same way. About 200 spores were counted and the per cent of spore germination was calculated in comparison with the control assay $(32,38)$.

\section{Fungal morphogenesis study}

For evaluating morphological alterations caused by the essential oil in A. niger P-03 a sample of mycelium was taken 
from the periphery of a 10-days-old fungal colony grown on SA at $25-28^{\circ} \mathrm{C}$ containing the essential oil $(80 \mu \mathrm{L} / \mathrm{mL})$. The samples were fixed in lacto-phenol-cotton blue stain and observed under the microscope at $400 \mathrm{x}$ to examine morphological abnormalities. Control assay without essential oil was tested in the same way (38).

All antifungal assays were carried out in duplicate and the results were expressed as an average of the two parallel assays.

\section{Statistical analysis}

Statistical analysis was performed to determine significant differences $(\mathrm{P}<0.05)$ by the Tukey test in the mycelial radial growth assays. For this the Sigma stat 2.03 computer program was used.

\section{RESULTS}

Results of the inhibitory effect of $C$. zeylanicum essential oil in a solid medium on some potentially pathogenic Aspergillus species are shown in Table 1 . The oil at $320-80 \mu \mathrm{L} / \mathrm{mL}$ strongly inhibited the growth of all assayed strains. $40 \mu \mathrm{L} / \mathrm{mL}$ was the $\mathrm{MIC}_{50}$ (lowest concentration causing a growth inhibition of 50 percent or more of the assayed strains), while $80 \mu \mathrm{L} / \mathrm{mL}$ was the $\mathrm{MIC}_{90}$ (lowest concentration causing a growth inhibition of 90 percent or more of the assayed strains) found for $C$. zeylanicum essential oil. The essential oil at 320 to $40 \mu \mathrm{L} / \mathrm{mL}$ provided growth inhibition zones with diameter equal to or higher than the ones caused by standard antifungals (amphotericim B and ketoconazole).

Fig. 1, 2 and 3 show the effect of $C$. zeylanicum essential oil $(80,40$ and $20 \mu \mathrm{L} / \mathrm{mL})$ and ketoconazole on the radial mycelial growth of A. flavus LM-247, A. fumigatus ATCC-40640 and A. niger $\mathrm{P}-03$ using the poisoned substrate technique. The essential oil provided a fungicidal effect noted by total inhibition of the mycelial growth along 14 days of exposure. The oil provided significant $(\mathrm{P}<0.05)$ inhibitory effect on the mycelial growth when compared with the control assay and ketoconazole. Only A. niger showed small mycelial growth up to 8 days of exposure when exposed to $20 \mu \mathrm{L} / \mathrm{mL}$ of the oil.

Ketoconazole showed no significant $(\mathrm{P}<0.05)$ reduction in the mycelial growth after 14 days of exposure in comparison with the control assay. Ketoconazole was inserted in the radial mycelial growth assay because no tested strain showed resistance to it in the MIC assay.

Results obtained from the effect of $C$. zeylanicum essential oil $(80,40$ and $20 \mu \mathrm{L} / \mathrm{mL})$ on spore germination of $A$. flavus LM247, A. fumigatus ATCC-40640 and A. niger P-03 are showed in Table 2. The oil at different concentrations caused an interesting inhibition of the spore germination. A $100 \%$ inhibition was found at 80 and $40 \mu \mathrm{L} / \mathrm{mL}$ of the oil, while it was over 90 and $80 \%$ at 20 $\mu \mathrm{L} / \mathrm{mL}$ for A. flavus and A. fumigatus, respectively. A. niger presented a $25 \%$ of spore germination inhibition at $20 \mu \mathrm{L} / \mathrm{mL}$.

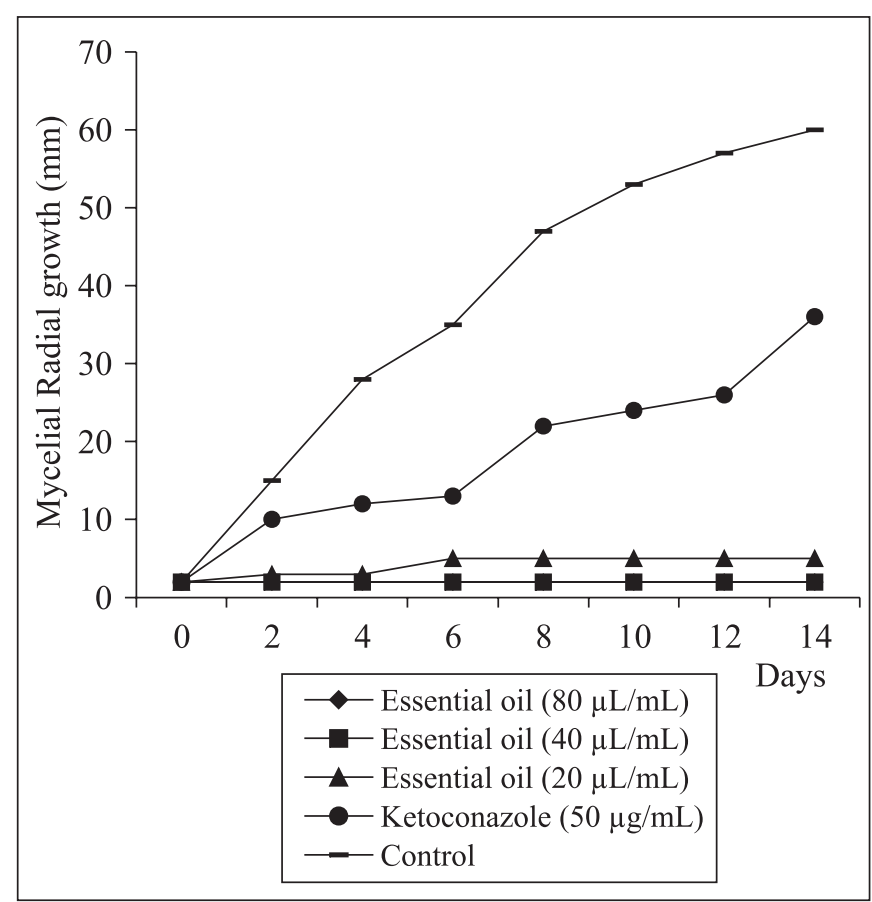

Figure 1. Effect of $C$. zeylanicum essential oil and ketoconazole on the radial mycelial growth kinetic of $A$. flavus LM-247.

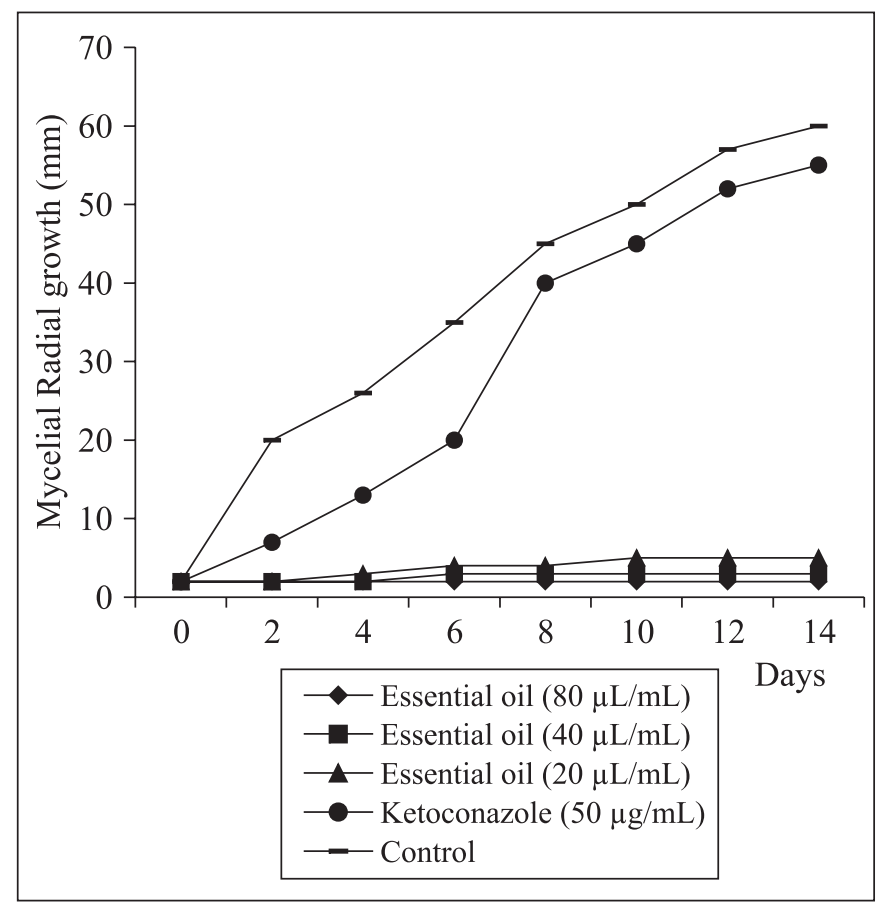

Figure 2. Effect of C. zeylanicum essential oil and ketoconazole on the radial mycelial growth kinetic of A. fumigatus ATCC40640. 
Table 1. Inhibitory effect of $C$. zeylanicum essential oil on the growth of some Aspergillus species (results expressed in millimeters of mould growth inhibition zones).

\begin{tabular}{ccccccccccccc}
\hline & \multicolumn{4}{c}{ C. zeylanicum essential oil $(\mu \mathrm{L} / \mathrm{mL})$} & \multicolumn{5}{c}{ Control } \\
\cline { 2 - 11 } Moulds & 320 & 160 & 80 & 40 & 20 & 10 & 5 & $\begin{array}{c}\text { Amp B a } \\
(100 \mu \mathrm{g} / \mathrm{mL})\end{array}$ & $\begin{array}{c}\text { Ketoc }^{\mathrm{b}} \\
(50 \mu \mathrm{g} / \mathrm{mL})\end{array}$ & Viab $^{\mathrm{c}}$ \\
\hline A. fumigatus ATCC-16913 & 22 & 20 & 18 & 12 & 8 & 0 & 0 & 8 & 18 & + \\
A. fumigatusATCC-40640 & 25 & 20 & 17 & 13 & 0 & 0 & 0 & 0 & 10 & + \\
A. niger P-03 & 24 & 17 & 12 & 0 & 0 & 0 & 0 & 12 & 10 & + \\
A. niger LM-257 & 22 & 20 & 15 & 6 & 0 & 0 & 0 & 8 & 10 & + \\
A. flavusATCC-16013 & 20 & 17 & 10 & 11 & 0 & 0 & 0 & 0 & 24 & + \\
A. flavusLM-247 & 18 & 16 & 11 & 10 & 0 & 0 & 0 & 7 & 15 & + \\
A. parasiticus ATCC-15517 & 17 & 11 & 8 & 0 & 0 & 0 & 0 & 8 & 20 & + \\
A. parasiticus NRRL-2999 & 20 & 17 & 12 & 13 & 0 & 0 & 0 & 7 & 20 & + \\
A. terreus UP-03 & 17 & 15 & 13 & 10 & 0 & 0 & 0 & 0 & 18 & + \\
A. terreus ATCC-7860 & 20 & 18 & 14 & 12 & 0 & 0 & 0 & 0 & 20 & + \\
A. ochraceus ATCC-7860 & 26 & 20 & 17 & 15 & 0 & 0 & 0 & 5 & 12 & + \\
A. ochraceus LM-06 & 23 & 20 & 17 & 15 & 0 & 0 & 0 & 0 & 12 & + \\
\hline
\end{tabular}

${ }^{\mathrm{a}}$ amphotericin B; ${ }^{\mathrm{b}}$ ketoconazole; ${ }^{\mathrm{c}}$ strain viability: ability of the strain to grow in Sabouraud agar without adding essential oil or synthetic antibiotic.

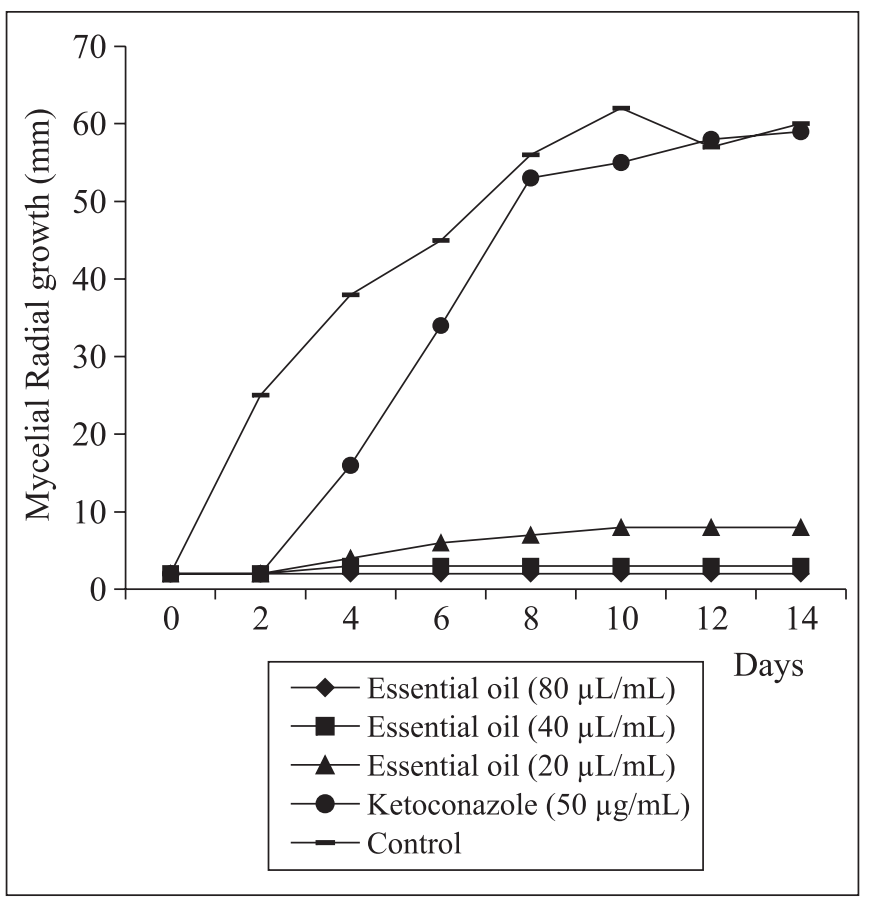

Figure 3. Effect of $C$. zeylanicum essential oil and ketoconazole on the radial mycelial growth kinetic of A. niger P-03.

Spores which germinated when exposed to $20 \mu \mathrm{L} / \mathrm{mL}$ of essential oil produced smaller germ tubes (early growing hyphae) in comparison with the control assay (data not showed).
Table 2. Inhibition of $C$. zeylanicum essential oil on spore germination of Aspergillus species (results expressed in percent of spore germination inhibition in comparison with the control assay).

\begin{tabular}{lccc}
\hline \multirow{2}{*}{ Moulds } & \multicolumn{3}{c}{ C. zeylanicum essential oil } \\
\cline { 2 - 4 } & $20 \mu \mathrm{L} / \mathrm{mL}$ & $40 \mu \mathrm{L} / \mathrm{mL}$ & $80 \mu \mathrm{L} / \mathrm{mL}$ \\
\hline A. flavus LM-247 & $92 \%$ & $100 \%$ & $100 \%$ \\
A. fumigatus ATCC-40640 & $86 \%$ & $100 \%$ & $100 \%$ \\
A. niger P-03 & $25 \%$ & $100 \%$ & $100 \%$ \\
\hline
\end{tabular}

Observations of $A$. niger examined under the light microscope at $400 \mathrm{x}$ magnification after exposure to $80 \mu \mathrm{L} / \mathrm{mL}$ of C. zeylanicum essential oil showed some morphological abnormalities (Fig. 4). Microscopic examination of the control mycelium (untreated cell) showed a regular cell structure with homogenous cytoplasm, clearly visible sterigmata bearing conidia and profuse conidiation on a large and radiated conidial head. The mycelial growth of $A$. niger in the medium containing the essential oil appeared to present morphological changes with a heterogeneous mycelial structure. In addition, the alterations observed included decreased conidiation (lack of sporulation), visible loss of cytoplasm content, loss of pigmentation, aberrant development of hyphae and fragmentation. The essential oil clearly caused reduction in conidial heads, with distorted presence of conidiophores. 


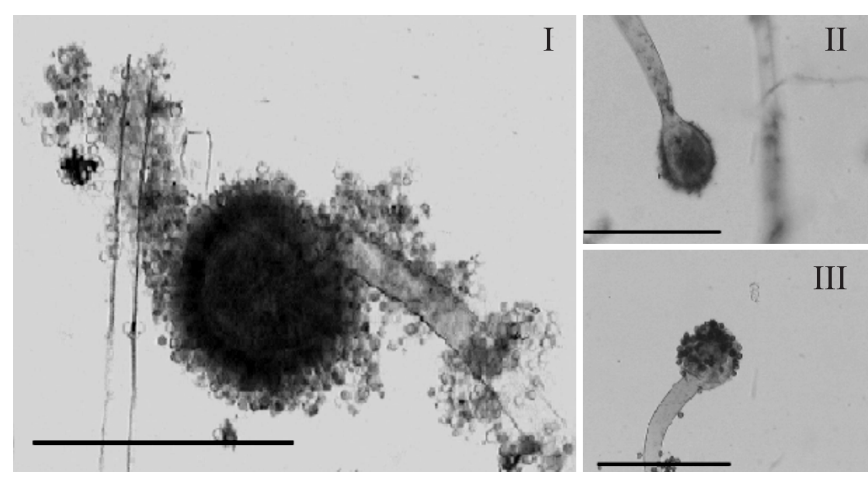

Figure 4. Light microphotographs of A. niger mycelium growing on AS without or with C. zeylanicum essential oil during 7 days of incubation at $25-28^{\circ} \mathrm{C}$. (I) Control conidial head of A. niger, large and radiated, development of vesicle on conidiophore, conidia clearly visible, Bar $100 \mu \mathrm{m}$. (II-III) Modifications of conidial head of A. niger induced by $80 \mu \mathrm{L} /$ $\mathrm{mL}$ of $C$. zeylanicum essential oil showing clear decrease in conidiation, Bar $100 \mu \mathrm{m}$.

\section{DISCUSSION}

This report describes the effectiveness of $C$. zeylanicum essential oil against Aspergillus species by different testing procedures. A wide range of antifungal activities was found. Preliminary experiments were carried out in vitro using the solid medium diffusion procedure in order to found the MIC of the essential oil on 12 Aspergillus strains on the basis of the diameter of mould growth inhibition zones. The essential oil up to $80 \mu \mathrm{L} / \mathrm{mL}$ caused a strong mould growth inhibition. AntiAspergillus activity presented a dose dependent effect.

The poisoned substrate technique showed a strong fungicidal effect of C. zeylanicum essential oil at 80 and $40 \mu \mathrm{L} /$ $\mathrm{mL}$ with a sustained and broad spectrum of inhibition over time. However, at $20 \mu \mathrm{L} / \mathrm{mL}$ of the oil occurred a steady slow growth rate during the first part of the period and disappearing after 8 days of exposure. Soliman \& Badea (40) reported complete inhibition of A. flavus, A. parasiticus and A. ochraceus by cinnamon oil $(<500 \mathrm{ppm})$. It has been reported that the inhibition of mould mycelial growth (fungistatic or fungicidal effect) in solid or liquid medium by essential oils over a wide range of concentrations has been accompanied by concomitant decease or total inhibition of mycotoxins production (e.g. by Aspergillus parasiticus, A. ochraceus, Fusarium graminearum, $F$. proliferatum $)(4,5,15,26,33)$.

The essential oil presented an intense suppressing effect on the fungal spore germination. In agreement with earlier researches $(32,38)$ the inhibition of spore germination caused by $C$. zeylanicum essential oil was in a dosage response manner. The capability of essential oils to inhibit fungal spore germination has been noted in other studies using different testing methods $(31,34,38)$.

Earlier reports showed that some essential oils are able to inhibit the mycelial growth of fungi in laboratorial media and foodstuffs $(4,33,43)$. However, the antifungal property of different essential oils ranges from a narrow to wide spectrum depending on the assayed essential oil, its concentration and the target fungal $(8,15,18,36,46)$.

The antifungal property of phytochemicals found in $C$. zeylanicum essential oil (e.g. mono- and sesqui-terpenes, phenols, cynnamaldheyde) could involve inhibition of extracellular enzymes synthesis and the disruption of the cell wall structure resulting in lack of cytoplasm, damage of integrity and ultimately the mycelial death. Cytoplasm granulation, cytoplasm membrane rupturing, cytoplasm hyperacidity, break down of the electron transport chain, $\mathrm{H}^{+}$-ATPase and channel inhibition are some structural and metabolic events possibly related to the antifungal property of essential oils $(9,10,25)$. It is also reported that essential oils are able to interfere into the mitochondrial membrane system by a membrane-disruptive activity closely associated with the enzymatic reactions, such as respiratory electron transport, protein transport and coupled phosphorylation $(4,35)$.

Velluti et al. (11) report that eugenol (a phenolic compound known as major component of $C$. zeylanicum essential oil) presents its antimicrobial activity attributed to the presence of an aromatic nucleus and a phenolic $\mathrm{OH}$ group known to be reactive and to form hydrogen bonds with active sites of target enzymes. Although, the antimicrobial activity of an essential oil is attributed mainly to its major components, the synergistic or antagonistic effect of compounds in minor percentage in the mixture has to be considered $(15,42)$.

The observations of light microscopy showed that the main morphological changes caused by $C$. zeylanicum essential oil on A. niger were associated with the degeneration of fungal hyphae causing leakage of cytoplasm content and loss of conidiation. These modifications in the cytological structure may be related to the interference of the essential oil with the enzymes responsible for wall synthesis as previously cited by other researchers $(39,45)$. De Billerbeck et al. (16) noted that Cymbopogon nardus (L.) W. Watson essential oil was able to cause morphological changes in A. niger including heterogeneous mycelium structure, granular/vesicular aspect of the cytoplasm content and complete degeneration of fungal hyphae resulting in an empty hyphae tip and cytoplasm retraction. Ultrastructural changes were smooth cell walls, depressions (like craters) on the cell surface. Such changes could be related to the interference of its components on enzymatic reactions of wall synthesis, which affects fungal morphogenesis and growth.

Sharma and Tripathi (38) noted that Citrus sinensis (L.) Osberk essential oil caused reduction in the conidial heads, poorly developed sterigmata and distorted (squashed and 
flattened) conidiophores in A. niger. Anomalous empty, budded and flattened hyphae and cell wall destruction was also found. These effects results in the death of hyphae suggesting that the essential oil antifungal property is a result of its attack on the cell wall and retraction of cytoplasm. Rasooli and Owlia (34) observed that thyme oils provided irreversible damage to cell wall (degenerative changes), cytoplasm membrane (irregular, dissociated from cell wall, invaginated) and nuclear membrane (folding) of Aspergillus parasiticus.

In conclusion, our results indicate that essential oils could find a practical and rational use in the inhibition of mould growth. Particularly, C. zeylanicum essential oil possesses strong antiAspergillus activity inhibiting the growth, spore germination and causing deleterious cellular morphological changes of different Aspergillus species. The broad inhibition of fungal growth and sporulation by $C$. zeylanicum essential oil, in addition to its availability as natural volatile product, justifies its possible rational use as an alternative antifungal compound to control the growth and dissemination of pathogen Aspergillus species.

\section{RESUMO}

\section{Efeito do óleo essencial de Cinnamomum zeylanicum Blume sobre o crescimento e morfogênese de algumas espécies de Aspergillus potencialmente patogênicas}

Cinnamomum zeylanicum Blume é uma planta conhecida por apresentar ampla variedade de propriedades medicinais. Portanto, este estudo teve por objetivo avaliar a interferência do óleo essencial $C$. zeylanicum sobre o crescimento e morfogênese de algumas espécies de Aspergillus potencialmente patogênicas. O óleo essencial testado apresentou potente efeito antifúngico demonstrado pela visualização de grandes zonas de inibição de crescimento de todas as linhagens testadas. Os valores de $\mathrm{CIM}_{50}$ e de $\mathrm{CIM}_{90}$ foram 40 e $80 \mu \mathrm{L} / \mathrm{mL}$, respectivamente. Nas concentrações de 80,40 e $20 \mu \mathrm{L} / \mathrm{mL}$ o óleo demonstrou um potente efeito fumigante, inibindo o crescimento micelial radial de A. niger, A. flavus e A. fumigatus ao longo de 14 dias de exposição. A 80 e $40 \mu \mathrm{L} / \mathrm{mL}$ o óleo essencial promoveu inibição de $100 \%$ da germinação de esporos, das três espécies de Aspergillus citadas anteriormente. Além disso, alterações morfológicas no crescimento fúngico foram observadas sob microscopia óptica após exposição ao óleo essencial, como diminuição da conidiação, perda citoplasmática, perda de pigmentação e rompimento da estrutura fúngica (hifa) indicando degeneração da parede celular. Diante do exposto, conclui-se que o óleo essencial de C. zeylanicum poderia ser empregado como potente composto antifúngico, particularmente, prevenindo crescimento de espécies de Aspergillus.

Palavras-chave: Aspergillus, Cinnamomum zeylanicum Blume, óleo essencial, atividade antifúngica.

\section{REFERENCES}

1. Adam, K.; Sivropoulou, A.; Kokkini, S.; Lanaras, T.; Arsenakis, M. (1998). Antifungal activities of Origanum vulgare subsp. hirtum, Mentha spicata, Lavandula angustifolia, and Salvia fruticosa essential oils against human pathogenic fungi. J. Agric. Food Chem., 46, 1739-1745.

2. Almeida, E.R. (1993). Plantas medicinais brasileiras. Hemus Editora, São Paulo.

3. Almeida, M.B.; Bussamra, M.H.; Rodrigues, J.C. (2006). Allergic bronchopulmonary aspergillosis in paedriatric cystic fibrosis patients. Paed. Resp. Rev., 7, 67-72.

4. Atanda, O.O.; Akpan, I.; Oluwafemi, F. (2006). The potential of some essential oils in the control of A. parasiticus CFR 223 and aflatoxin production. Food Cont., 18, 601-607.

5. Basilico, M.Z.; Basilico, J.C. (1999). Inhibitory effects of some spices essential oils on Aspergillus ochraceus NRRL 3174 growth and ochratoxin A production. Lett. Appl. Microbiol., 29, 238-241.

6. Battilani, P.; Magan, N.; Logrieco, A. (2006). European research on ochratoxin A in grapes and wine. Int J. Food Microbiol., 11, S2-S4.

7. Bauer, A.W.; Kirby, W.M.M. (1966). Antibiotic susceptibility testing by standardized single disk method. Am. J. Clin. Pathol., 45, 493-496.

8. Baydar, H.; Sagdiç, O.; Ozkan, G.; Karadogan, T. (2004). Antibacterial activity and composition of essential oils from Origanum, Thymbra and Sartureja species with commercial importance in Turkey. Food Cont., 15, 169-172.

9. Brul, S.; Coote, P. (1999). Preservative agents in foods: mode of action and microbial resistance mechanisms. Int. J. Food Microbiol., $50,1-17$.

10. Burt, S. (2004). Essential oils: their antibacterial properties and potential applications in foods - a review. Int. J. Food Microbiol., 94, 223-253.

11. Canuto, M.M.; Rodero, F.G. (2002). Antifungal drug resistance to azoles and polyenes. Lancet. Infect. Dis., 2, 550-563.

12. Chakrabarti, A.; Marak, R.S.K.; Sing, S.; Gupta, S.O.; Hurst, S.F.; Padhye, A.A. (2006). Brain abcess due to Aspergillus nidulans. J. Med. Mycol., 16, 100-104.

13. Chamilos, G.; Kontoyianis, D.P. (2005). Update on antifungal drug resistance mechanisms of Aspergillus fumigatus. Drug Res. Update, 8, 344-358.

14. Curtis, L.; Conroy, L.; Coli, S.; Baker, K.; Our, C.H.; Hershow, R.; Norlock-Cruz, F.; Scheff, P. (2005). Aspergillus surveillance project at a large tertiary-care hospital. J. Hosp. Infect., 59, 188-196.

15. Daferera, D.J.; Ziogas, B.N.; Polissiou, M.G. (2003). The effectiveness of plant essential oils on the growth of Botrytis cinerea, Fusarium sp. and Clavibacter michiganenesis subsp. michiganenesis. Crop. Protect., 22, 39-34.

16. de Billerberck, V.G.; Roques, C.R.; Bessière, J.M.; Fonvieille, J.L.; Dargent, R. (2001). Effect of Cymbopogon nardus (L.) W. Watson essential oil on the growth and morphogenesis of Aspergillus niger. Can. J. Microbiol., 47, 9-17.

17. Desselberger, V. (2000). Emerging and re-emerging infectious disease. J. Inf. Dis., 40, 3-15.

18. Duarte, M.C.T.; Figueira, G.M.; Sartoratto, A.; Rehder, V.L.G.; Delarmelina, C. (2005). Anti-Candida activity of Brazilian medicial plants. J. Ethnopharm., 97, 305-311.

19. Dubey, A.; Patwardhan, R.V.; Sampth, S.; Santoshi, V.; Kolluri, S.; Nanda, A. (2006). Intracranial fungal granuloma: analysis of 40 patients and review of the literature. Surg. Neurol., 63, 254-260.

20. Gayoso, C.W.; Lima, E.O.; Trajano, V.N.; Pereira, F.O.; Souza, E.L.; Lima, I.O.; Navarro, D.F. (2005). Sensitivity of fungi isolated from onychomycosis to Eugenia cariophyllata essential oil and eugenol. Fitoterapia, 76, 247-249.

21. Georgopapadakou, N.H. (2002). Infectious diseases 2001: drug resistance, new drugs. Drug Res., 5, 181-191. 
22. Hadacek, F.; Greger, H. (2000). Testing of antifungal natural products: methodologies, comparability of results and assay choice. Phytochem. Anal., 11, 137-148.

23. Kawashima, L.M.; Valente, S.L.M. (2006). Incidência de fumonisina $\mathrm{B}_{1}$, aflatoxinas $\mathrm{B}_{1}, \mathrm{~B}_{2}, \mathrm{G}_{1}$ e $\mathrm{G}_{2}$, ocratoxina $\mathrm{A}$ e zearalenona em produtos de milho. Cienc. Tecnol. Alim., 26, 516-521.

24. Lima, I.O.; Oliveira, R.A.G.; Lima, E.O.; Souza, E.L.; Farias, N.P.; Navarro, D.F. (2005). Inhibitory action of some phytochemicals on yeasts potentially causing of opportunistic infections. Rev. Bras. Cien. Farm., 41, 199-203.

25. Lopez Díaz, T.M.L.; González, C.J.; Moreno, B.; Otero, A. (2002). Effect of temperature, water activity, $\mathrm{pH}$ and some antimicrobials on the growth of Penicillium oslonii isolated from the surface of Spanish fermented meat sausage. Food Microbiol., 19, 1-7.

26. Marín, S.; Velluti, A.; Ramos, A.J.; Sanchis, V. (2004). Effect of essential oils on zearalenone and deoxynivalenol production by Fusarium graminearum in non-sterilized maize grain. Food Microbiol., 21, 313-318.

27. Mishra, N.; Upma, K.; Shukla, D. (2000). Antifungal activity of essential oil of Cinnamomum zeylanicum. J. Essent. Oil Res., 3, 97110 .

28. Moreira, A.C.P.; Lima, E.O.; Souza, E.L.; Van Dingenen, M.A.; Trajano, V.N. (2007). Inhibitory effect of Cinnamomum zeylanicum Blume (Lauraceae) essential oil and $\beta$-pinene on the growth of dematiaceous moulds. Braz. J. Microbiol., 38, 33-38.

29. Nostro, A.; Blanco, A.R.; Cannatelle, M.A.; Enea, V.; Flamini, G.; Morelli, I.; Roccaro, A.S.; Alonzo, V. (2004). Susceptibility of methicillin-resistant staphylococci to oregano essential oil, carvacrol and thymol. FEMS Microbiol. Lett., 230, 191-195.

30. Pasquier, F.; Croxo, C.; Melliez, H.; Porte, H.; Bourgeois-Petit, E.; Cambier, N.; Rose, S. (2006). L'aspergillome pulmonaire: une complication possible de lá drepanocytose. La Revue de Medicine Interne, 27, 260-263.

31. Pattnaik, S.; Subramanyan, V.R.; Kole, C. (1996). Antibacterial antifungal activity of ten essential oils in vitro. Microbios, 86, 121126.

32. Rana, B.K.; Singh, U.P.; Taneja, V. (1997). Antifungal activity and kinetics of inhibition by essential oil isolated from leaves of Aegle marmelos. J. Ethnopharm., 57, 29-34.

33. Rasooli, I.; Abyaneh, M.R. (2004). Inhibitory effect of Thyme oils on growth and aflatoxin production by Aspergillus parasiticus. Food Cont., 15, 479-483.
34. Rasooli, I.; Owlia, P. (2005). Chemoprevention by thyme oils of Aspergillus parasiticus growth and aflatoxin production. Phytochemistry, 66, 2851-2856.

35. Rasooli, I.; Rezaei, M.B.; Allameh, A. (2006). Growth inhibition and morphological alterations of Aspergillus niger by essential oils from Thymus eriocalyx and Thymus x-porlock. Food Conti., 17, 359-364.

36. Sahin, F.; Gulluce, M.; Daferera, D.; Sokmen, A.; Polissiou, M.; Agar, G.; Ozer, H. (2004). Biological activities of the essential oils and methanol extract of Origanum vulgare ssp. vulgare in the Eastern Anatolia region of Turkey. Food Cont., 15, 549-557.

37. Saleemulla, A.I.; Khalil, I.A.; Shah, H. (2006). Aflatoxin contents of stored and artificially inoculated cereals and nuts. Food Chem, 98, 699-703.

38. Sharma, N.; Tripathi, A. (2006). Effects of Citrus (L.) Osbeck epicarp essential oil on growth and morphogenesis of Aspergillus niger (L.) Van Tieghem. Microbiol. Res., In press, 2007.

39. Shukla, A.C.; Shahi, S.K.; Dixit, A. (2000). Epicarp of Citrus sinensis: a potential source if natural pesticides. Ind. Phytopath., 53, 468-471.

40. Soliman, K.M.; Badeae, R.I. (2002). Effect of oil extracted from some medicinal plants on different mycotoxigenic fungi. Food Chem. Toxicol., 144, 1669-1675.

41. Souza, E.L.; Lima, E.O.; Freire, K.R.L.; Sousa, C.P. (2005). Inhibition action of some essential oils and phytochemicals on the growth of moulds isolated from foods. Braz. Arch. Biol. Technol., 48, 245250 .

42. Souza, E.L.; Stamford, T.L.M.; Lima, E.O.; Trajano, V.N. (2007). Effectiveness of Origanum vulgare L. essential oil to inhibit the growth of food spoiling yeasts. Food Cont., 18, 409-413.

43. Thyagaraja, N.; Hosono, A. (1996). Effect of spice extract on fungal inhibition. Lebensm-Wiss u-Technol., 29, 286-288

44. Velluti, A.; Sanchis, V.; Ramos, A.J.; Egido, J.; Marin, S. (2003). Inhibitory effect of cinnamon, clove, lemongrass, oregano and palmarose essential oils on growth and fumonisin $\mathrm{B}_{1}$ production by Fusarium proliferatum in maize grain. Int. J. Food Microbiol., 89, 145-154.

45. Zambonelli, A.; Zechini d'Aulerio, A.; Bianchi, A.; Albasini, A. (1996). Effects of essential oil on phytopathogenic fungi. Phytopath., 144, 491-494.

46. Zygadlo, J.A.; Grosso, N.R. (1995). Comparative study of the antifungal activity of essential oils from aromatic plants growing wild in the central region of Argentina. Flavor and Fragrance Journal., 10, 113-118. 